\title{
Isolation and Characterization of a Novel RIP from Trichosanthes dioica having Anticancer Activity
}

\author{
Tapu Ghosh ${ }^{1 *}$, Laishram Indira Singha ${ }^{2}$ and Keshab Barman ${ }^{3}$ \\ ${ }^{1}$ Dept. of Biotechnology, Assam Don Bosco University, Sonapur, Assam, India \\ ${ }^{2}$ Dept. of Biotechnology, St. Anthony's College, Shillong, Meghalaya, India \\ ${ }^{3}$ ICAR-NRC on Pig, Rani, Guwahati, Assam India \\ *Corresponding author
}

\section{A B S T R A C T}

\section{Ke y w o r ds \\ Anticancer, \\ Cucurbitacea, \\ MTT-Assay, \\ Purification, \\ Ribosome \\ inactivating \\ property, Secondary \\ structure}

\section{Article Info}

Accepted:

04 August 2020

Available Online:

10 September 2020

\begin{abstract}
Plants of Cucurbitaceae family have shown to possess proteins like ribosome-inactivating proteins (RIPs) which have shown promising results against microbes and are also being explored for anti-cancer activities. The present study was designed to isolate a novel protein from a Cucucrbitaceae species which shows Ribosome inactivating property, and which in turn may be effective against cancer i.e. showing anticancer activity. Trichosanthes dioica seeds were taken which are not explored enough for proteins which can inactivate ribosomes and in turn may be used for their medicinal property in cancer treatment etc. Purification for Ribosome Inactivating Proteins (RIPs) resulted in an approx. $32 \mathrm{KDa}$ band from Trichosanthes dioica seeds. Ribosome inactivating property was tested using rabbit reticulocyte which gave a positive result. Anticancer activity of the isolated protein was tested on cancerous cell lines MDA and HL-60 along with PBLs as control cell line. The results showed that the protein is effective against cancerous cell lines with minimal effect on normal cell lines. The isolated protein was found to be less toxic to normal cells and more effective as anti-proliferative agents than Momordica charantia derived protein which was used as positive control. Also, the isolated protein showed a protein profile with predominance of alpha-helical elements. The study showed that $\mathrm{N}$ glycosidase activity of the protein plays a great role as the mode of action as found in the secondary structure homology analysis.
\end{abstract}

\section{Introduction}

Plants from ancient times have been used as a source of medicines. Numerous work has been conducted on the potential properties and applications of terrestrial plant extracts to develop new plant-based medicines for diseases such as cancer, and is still ongoing. Nevertheless, a number of recent studies have been carried out to improve the detection and management of cancer progression, but substantial research and scope for improvements still remain. The quest for anticancer agents from plant sources began in the 1950s when vinca alkaloids (vinblastin and vincristine) were discovered and produced, and cytotoxic podophyllotoxins were isolated (Gordon et al., 2005). Plants 
like that of the Cucurbitaceae family etc. are sources of proteins like ribosome-inactivating proteins (RIPs) which have shown promising results against microbes and are also being explored for anticancer activities. This could also play an important role in blocking the spread of certain pathogens by causing the death of infected cells. Ribosome inactivating proteins (RIPs) fall in the category of proteins which are studied for their selective toxicity. According to some researchers the toxic activity is due to the ability of the protein to inhibit protein synthesis by inactivating ribosomes through cleaving the $\mathrm{N}$-glycosidic bond at the $\mathrm{A}_{324}$ position of 28S RNA (Li et al., 1997)

Based on their physical properties RIPs are classified into three groups (Mundy et al., 1994). Type 1 RIPs are monomeric enzymes with molecular weight of $30 \mathrm{KDa}$. Pokeweed antiviral protein (PAP), saporin (from soapwort, Saponaria officinalis L.), and bRIP (from barley, Hordeum vulgare) translation inhibitor, are some exapmles of type 1 RIP (Asano et al., 1984; Barbieri et al., 1993; Irvin et al., 1975). Type 1 RIPs are basic proteins and found to share many highly conserved active cleft residues and secondary structure within the active site region (Barbieri et al., 1993; Husain et al., 1994; Mlsna et al., 1993; Monzingo et al., 1992). Most RIPs that have been characterized till date fall into type 1 class of RIPs (Asano et al., 1984). Type 2 RIPs are toxic heterodimeric proteins having enzymatic and lectin properties in separate polypeptide subunits, each of these sub units has molecular weight of around approximate 30 KDa. A polypeptide with RIP activity (Achain) is linked to a galactose binding lectin (B-chain) through a disulfide bond. Ricin and abrin are examples of Type-2 RIP (Olsnes et al., 1973 and 1982; Stirpe et al., 1978). Type 3 RIPs much less prevalent than type 1 or type 2 RIPs, they are basically inactive precursors (proRIPs) that require proteolytic processing events to occur between amino acids involved in formation of the active site (Mundy et al., 1994). Most type 3 RIPs have been characterized from maize and barley (Bass et al., 1992; Chaudhry et al., 1994; Reinbothe et al., 1994; Walsh et al., 1991), sorghum have also appeared to accumulate type 3 RIPs seeds (Nielsen and Boston, 2001; Hey et al., 1995; Seetharaman et al., 1996;).

The biggest drawbacks to synthetic drugs are the resulting side effects and cost. Using plant products like RIPs may solve many such problems and present a cost effective approach to deal with some of the deadliest diseases like cancer as side effects of plant derived products on living cells as compared to the synthetic drugs are low or minimal. In addition, some of the properties of RIPs like anti-viral and anticancer can be used to develop drug(s) for some specific virus (es) or specific tumor cell(s) against which drugs are yet to be discovered or to improve the existing ones by using the RIPs in immunotherapy as Immunotoxins. RIPs like ricin and abrin have shown to induce apoptosis in many cells and cell lines in previous studies (Griffiths et al., 1987). Some species of Cucurbitaceae family are yet to be explored for new RIPs which might help to better understand the mode of action of these proteins and also prove be more effective for cancer treatment. RIPs such as M. Balsamine Balsamine seeds are tested for their antioxidant properties and their DNase activity (Ajji et al., 2016).

In this study a novel protein isolated from Trichosanthes dioica of Cucurbitaceae family which upon testing exhibited ribosome inactivating property was tested for anticancer properties. This may pave the way for exploration of these proteins for potential use as anti-cancer agents in future. 


\section{Materials and Methods}

\section{Purification of RIP(s)}

Seeds were collected from the local market of Shillong, Meghalaya. The shelled Trichosanthes dioica seeds were crushed with mortar and pestle, and the seed powder obtained was extracted with 10 volumes of buffer A (20 mM phosphate buffer, $\mathrm{pH} 7.2$, $0.2 \mathrm{M} \mathrm{NaCl}$ ) with gentle stirring at $4^{\circ} \mathrm{C}$ overnight. The homogenate was centrifuged $\left(9,000 \mathrm{~g}, 4^{\circ} \mathrm{C}, 30 \mathrm{~min}\right)$, and protein was precipitated from the supernatant by ammonium sulfate (AS).

The mixture was centrifuged $\left(9,000 \mathrm{~g}, 4^{\circ} \mathrm{C}\right.$, $30 \mathrm{~min})$ at $50 \%$ and $85 \%$ saturation of AS in sequence. The pellets were separately dissolved in buffer B (5 mM PB, pH 7.0) and then extensively dialyzed against the same buffer.

After centrifugation to remove insoluble materials, the supernatant was applied to a CM-cellulose 52 column $(15.0 \mathrm{~cm} 2.0 \mathrm{~cm})$ preequilibrated with buffer B. Proteins were eluted with a linear gradient of $0-0.6 \mathrm{M} \mathrm{NaCl}$ in buffer B. The fractions (3.0 ml/tube) containing Trichosanthes dioica RIPs was pooled and dialyzed against buffer $\mathrm{C}(15 \mathrm{mM}$ Tris-HCl, $\mathrm{pH}$ 7.5).

The active fraction was further purified by FPLC on a superdex 75 10/300 GL column using buffered saline (PBS, 7.2) (Singh et al., 2003).

The eluent (resulted protein) was then further used for SDS-PAGE.

\section{Determination of molecular weight}

The molecular weight of the protein was determined by $10 \%$ SDS-PAGE along with a protein marker and found to be $\sim 32 \mathrm{KDa}$.
Assay of cell-free system protein biosynthesis inhibitory activity

\section{Non-radioactive luciferase reaction}

Flexi® Rabbit Reticulocyte Lysate System kit (L4540) was used with modifications for this assay. The reaction was assembled as follows:

$35 \mu 1$ of Flexi® Rabbit Reticulocyte Lysate, $0.5 \mu 1$ each of $1 \mathrm{mM}$ Amino Acid MixtureMinus Leucin and $1 \mathrm{mM}$ Amino Acid Mixture- Minus Methionine, $1.4 \mu 1$ of $2.5 \mathrm{M}$ Potassium Chloride, $1 \mu \mathrm{l}$ of RNasin ${ }^{\circledR}$ Ribonuclease Inhibitor $(40 \mathrm{u} / \mu \mathrm{l}), \quad 1 \mu \mathrm{l}$ Luciferase Control RNA $(1 \mathrm{mg} / \mathrm{ml})$, rest Nuclease-Free Water was added to make the final volume to $50 \mu 1$ for control. For test sample reaction $30 \mu \mathrm{l}$ of $0.03 \mathrm{mg} / \mathrm{ml}$ of protein (test sample) was also added. For positive control, concentration of RIP from Momordica charantia was kept same as that of the test sample.

The translation reaction mix was incubated at $30^{\circ} \mathrm{C}$ for $60-90$ minutes. The synthesis of functional luciferase was detected using a standard luciferase assay using a scintillation counter.

Use of scintillation counter: $50 \mu$ of the Luciferase assay reagent was dispensed into scintillation tubes, one tube per sample. The Luciferase assay reagent was kept at ambient temperature prior to detect the rate of translation. $2.5 \mu 1$ of cell lysate was added to the scintillation tubes containing the Luciferase assay reagent and mixed by pipetting 2-3 times briefly. The sample was placed in a microcentrifuge tube, then the tube was placed in a scintillation vial. Since, the enzymatic reaction produces light at all wavelengths, the samples were read with all channels open (open window). To reduce background counts, 10-30 second gaps were taken before counting. 


\section{Test for anticancer activity}

To test for anticancer activity cancerous cell lines HL 60 and MDA-MB- 453 were used. Peripherl blood lymphocytes (PBls) served as control.

\section{Total protein concentration of cancerous cells and PBLs}

From PBLs: The cell culture was taken from the incubator and centrifuged for 5 mins at $900 \mathrm{~g}$ and the spent medium was discarded. Then $2 \mathrm{ml}$ of complete media was added and centrifuged at $900 \mathrm{~g}$ for $5 \mathrm{~min}$, the supernatant was thrown and number of cells were counted in a hemocytometer and around $3 \times 10^{6}$ of cells per $\mathrm{ml}$ were distributed in three different flasks: a) for control b) for test sample (protein) and c) positive control with known RIP. Then after three days, protein extraction was done from the three above mentioned flasks.

\section{From MDA-MB- 453 and HL 60}

Cell cultures of the two cell lines were subcultured in triplicates: a) for control b) for test sample (protein) and c) positive control with known RIP for each cell line (around $3 \times 10^{6}$ cells per $\mathrm{ml}$ ). Then after three days, protein extraction was done from the three above mentioned flasks for each cell line (Smith 1985).

Bradford method was used to calculate the protein concentration of isolated proteins from the cell lines.

\section{MTT Assay}

The effect of the RIP on the viability of all three cell lines cells were tested by using 3 [4,5-dimethylthiazol-2-yl]-2,5 diphenyl tetrazolium bromide (MTT) assay. Cells were seeded in 96-well flat-bottom tissue culture plates at a density of 105 cells/well (per 100 $\mu \mathrm{L}$ ) containing $10 \%$ fetal bovine serum (FBS) in Dulbecco's Modified Eagle Medium (DMEM) and incubated at $37^{\circ} \mathrm{C}$ in $5 \% \mathrm{CO} 2$. After $16 \mathrm{~h}$, the media was discarded, and each well was washed with phosphate-buffered saline (PBS) followed by the addition of RIP to each well at different concentrations with media. For suspension cell lines i.e. PBLs and HL-60 the cells were grown in culture tubes and media was discarded by spinning in centrifuge at $1,000 \mathrm{xg}, 4^{\circ} \mathrm{C}$ followed by addition of RIP as mentioned. After $24 \mathrm{~h}$ treatment, $10 \mu \mathrm{l}$ of MTT solution $(5 \mathrm{mg} / \mathrm{ml})$ was added to each well, and the plates were incubated for another $4 \mathrm{~h}$. MTT containing media was removed from each well, and 100 $\mu \mathrm{L}$ of DMSO was added, dissolving the formazan crystals. The absorbance was recorded in a microplate reader (Multiskan ${ }^{\mathrm{TM}}$ $\mathrm{GO})$ at the wavelength of $570 \mathrm{~nm}$. All experiments were performed in triplicate, and the relative cell viability (\%) was expressed as a percentage relative to the untreated cells (Freshney, 2010).

\section{Secondary structural analysis using Circular dichroism (CD)}

For secondary structure analysis CD spectra were recorded at $25^{\circ} \mathrm{C}$ including the far-UV region (200-250 nm) using JASCO 1000 with a $1 \mathrm{~mm}$ quartz cuvette (Micsonai 2015 and 2018).

\section{Results and Discussion}

Purification and molecular weight: The protein isolated from Trichosanthes dioica seeds was about $32 \mathrm{KDa}$ [Figure 1].

Assay of cell-free system protein biosynthesis inhibitory activity (rabbit reticulocyte kit): The test protein (from Trichosanthes dioica) showed ribosome inactivating properties which was almost like 
that of the positive control (i.e. RIP of Momordica charantia) or may be slightly better [Table 1].

\section{Test for anticancer activity}

\section{Effect on protein concentration}

After extracting protein from PBLs MDAMB- 453 and HL-60 cells treated with the Test Sample (protein from Trichosanthes dioica), positive control (protein from Momordica charantia) and untreated (i.e. control) it was found that in all treated cells the control had more amount of protein compared to the ones with test sample and positive control.

In the case of PBLs treated cells, the inhibition rate in those with the test sample was comparatively lower than the positive control rate, which suggests that the test sample inhibits protein synthesis in normal PBLs, but certain changes may help further the inhibition effect on normal cells [Table 2A].

On the other hand on extracting proteins from MDA-MB- 453 and HL-60 treated cells it was found that protein synthesis inhibition was more in cells with the test sample than with positive control.

This indicates that the test sample could have a greater anti-cancer effect on cell lines MDA-MB- 453 and HL-60 than that of positive control (Momordica charantia RIP) [Table 2B \& 2C.]. Also, the protein inhibition was found to be better against HL 60 than that of MDA-MB- 453.

\section{MTT test}

After performing the MTT test on PBLs, MDA-MB- 453 \& HL60 cells treated with the isolated protein and a positive control, it was observed that the isolated protein does have anticancer activity which was very evident in case of MDA-MB- 453 treated cells. Whereas in case of HL60 cells, though it seems to hamper the viability of the cells, but the effect is comparatively less than that in the case on MDA cells.

When PBLs (as normal cell lines) treated with the same isolated protein, it was found to affect the viability of the PBLs too but not to that great extent.

Which shows that the isolated protein affects the viability of the cancerous cell lines more, compared to the normal ones, hence some slight modifications and further study can lead to a better product. Also, the effect on normal cells (PBLs) was minimal and with some concentration it was better than the positive control [Figure 2A. 2B \& 2C].

Table.1 Assay of cell-free system protein biosynthesis inhibitory activity. For this Flexi® Rabbit Reticulocyte Lysate System kit (L4540) was used with modifications and readings were taken with the help of a scintillation counter

\begin{tabular}{|l|c|c|}
\hline Sample & Count Time & Spectral index of sample \\
\hline Negative Control & 1 Minute & 62.80 \\
\hline $\begin{array}{l}\text { Test Sample (protein from } \\
\text { Trichosanthes dioica ) }\end{array}$ & 1 Minute & 21.27 \\
\hline $\begin{array}{l}\text { Positive control (protein from } \\
\text { Momordica charantia) }\end{array}$ & 1 Minute & 21.67 \\
\hline
\end{tabular}


Table.2 Effect on protein concentration in A. PBLs B. MDA-MB- 453 C. HL- 60 cell lines after exposure to the test sample and positive control (RIP from Momordica charantia) for around 72 hours. Cell lines without any test protein served as negative control

A.

\begin{tabular}{|c|l|c|c|}
\hline Cell lines & \multicolumn{1}{|c|}{ Samples } & Absorbance at 595 & $\begin{array}{c}\text { Protein concentration } \\
(\boldsymbol{\mu g} / \mathbf{m l})\end{array}$ \\
\hline \multirow{2}{*}{ PBLs } & \begin{tabular}{l} 
Negative Control \\
\cline { 2 - 3 }
\end{tabular} & $\begin{array}{l}\text { Test Sample (protein } \\
\text { fromTrichosanthes dioica) }\end{array}$ & 0.113 \\
\hline & $\begin{array}{l}\text { Positive control (protein from } \\
\text { Momordica charantia) }\end{array}$ & 0.081 & 60 \\
\hline
\end{tabular}

B.

\begin{tabular}{|c|l|c|c|}
\hline Cell lines & Samples & $\begin{array}{c}\text { Absorbance at } \\
\mathbf{5 9 5}\end{array}$ & $\begin{array}{c}\text { Protein Concentration } \\
(\boldsymbol{\mu g} / \mathbf{m l})\end{array}$ \\
\hline \multirow{2}{*}{ MDA } & Negative Control & 0.089 & 189 \\
\cline { 2 - 4 } & $\begin{array}{l}\text { Test Sample (protein from } \\
\text { Trichosanthes dioica) }\end{array}$ & 0.04 & 88 \\
\hline & $\begin{array}{l}\text { Positive control (protein from } \\
\text { Momordica charantia) }\end{array}$ & 0.0426 & 94 \\
\hline
\end{tabular}

C.

\begin{tabular}{|c|c|c|c|}
\hline Cell lines & Samples & Absorbance at 595 & $\begin{array}{l}\text { Protein concentration } \\
(\mu \mathrm{g} / \mathrm{ml})\end{array}$ \\
\hline \multirow[t]{3}{*}{ HL 60} & Negative Control & 0.12 & 167 \\
\hline & $\begin{array}{l}\text { Test Sample (protein from } \\
\text { Trichosanthes dioica) }\end{array}$ & 0.05 & 70 \\
\hline & $\begin{array}{l}\text { Positive control (protein from } \\
\text { Momordica charantia) }\end{array}$ & 0.025 & 36 \\
\hline
\end{tabular}

Table.3 Percentage of secondary structures of the isolated RIP (test sample) predicted using CD analysis

\begin{tabular}{|c|c|c|}
\hline \% $\boldsymbol{\alpha}$-helix & \% $\boldsymbol{\beta}$-turn & \% Others \\
\hline 24.9 & 13 & 62.1 \\
\hline
\end{tabular}

Table.4 Homology details shared by the test proteins with other compounds/proteins

\begin{tabular}{|l|l|}
\hline Category name & Score \\
\hline Ankyrin repeat-containing domain & 0.67 \\
\hline BEACH domain & 0.56 \\
\hline Glycoside hydrolase, family 3, N-terminal domain & 0.25 \\
\hline $\begin{array}{l}\text { Type I PLP-dependent aspartate aminotransferase- } \\
\text { like (Major domain) }\end{array}$ & 0.14 \\
\hline Transferase (Phosphotransferase) domain 1 & 0.12 \\
\hline Metal-dependent hydrolases & 0.09 \\
\hline Leucine-rich Repeat Variant & 0.08 \\
\hline
\end{tabular}


Fig.1 Gel picture showing the test sample (protein isolated from Trichosanthes dioica) eluted with different concentration of buffer C. Lane 2-3 different concentration of the test sample.

Lane 1 is protein ladder

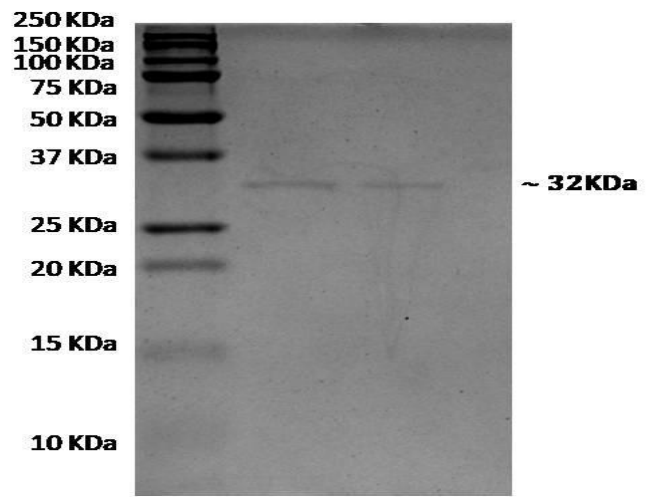

Fig.2 Absorbance values of MTT formazan products derived from cultured A. PBL, B. HL 60 and C. MDA-MB- 453 cells treated with varying concentration of test protein in comparison to the untreated control cells (conc. in $\mathrm{X}$-axis is undiluted protein, $10^{-1}$ to $10^{-5}$ different serial dilutions). The cytotoxic effects of the test compounds on cell lines were compared against the control using the MTT based assay. The ability of the cells to metabolise MTT was measured by taking the absorbance at $570 \mathrm{~nm}$. Cells exposed to water (cell culture grade) were used as negative control and for positive control varying concentration of protein from Momordica charantia was used. Values are expressed as mean \pm SEM (*denotes significance against untreated control cells at $\left.\mathrm{p}<0.0005^{* * *}, \mathrm{p}<0.001^{* *}, \mathrm{p}<* 0.005\right)$. Conc. is the undiluted sample of around $0.03 \mathrm{mg} / \mathrm{ml}$ concentration
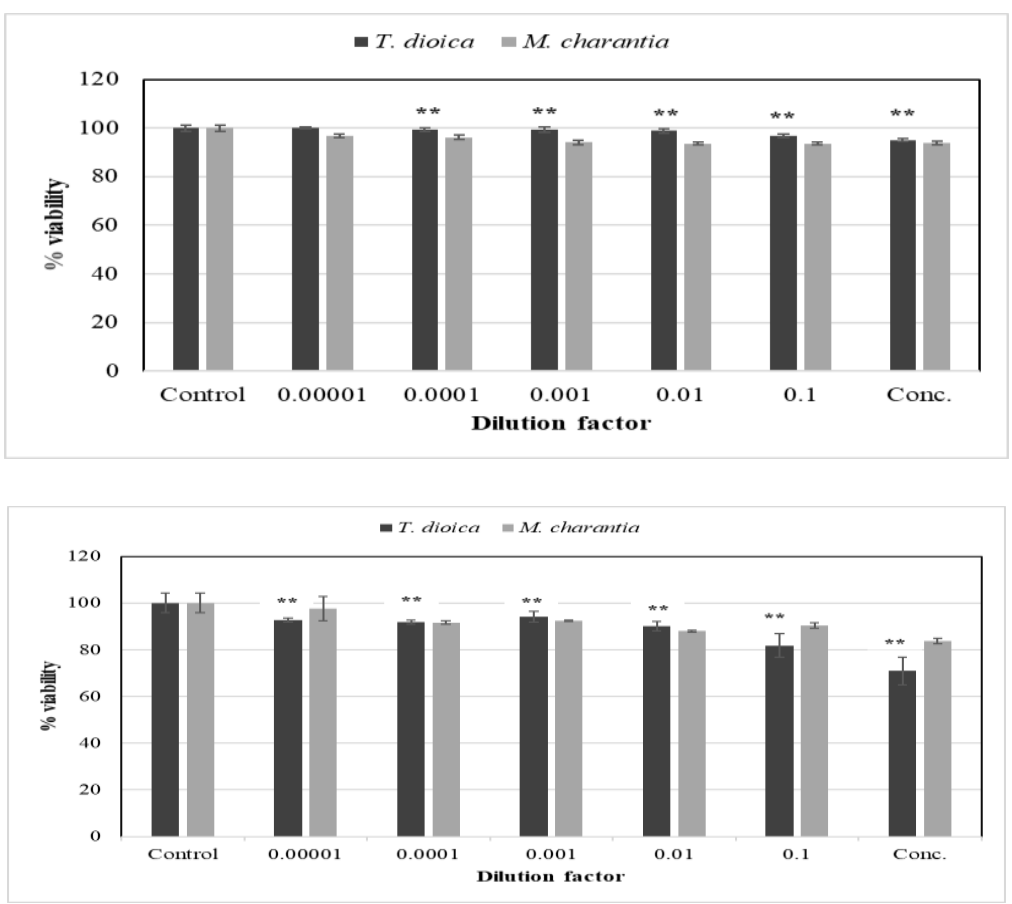


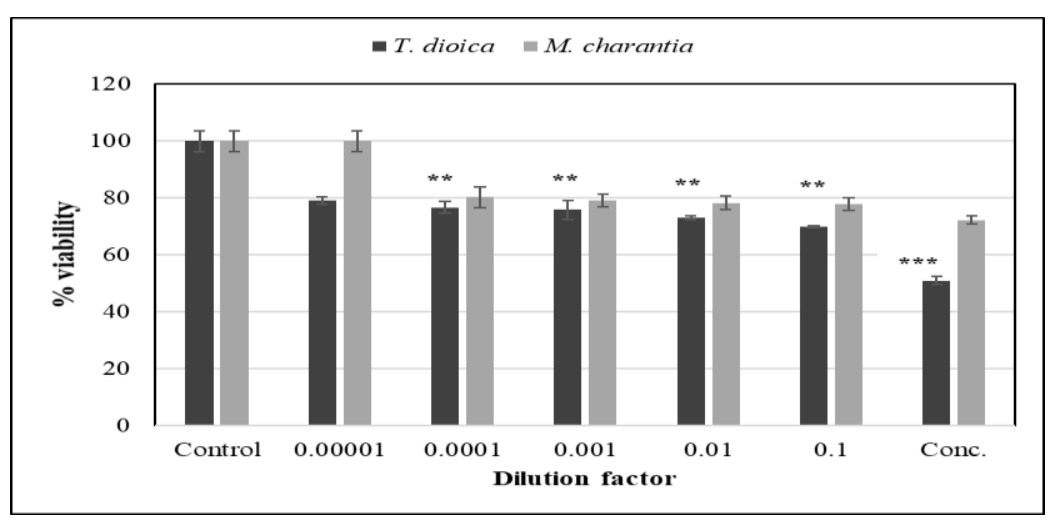

Fig.3 CD-spectral analysis test sample: RIP from Trichosanthesdioica. A. CD spectra using JASCO 1000. B. The spectra are presented as mean residue molar ellipticity, expressed in degree $\cdot \mathrm{cm} 2 / \mathrm{dmol}$

A.

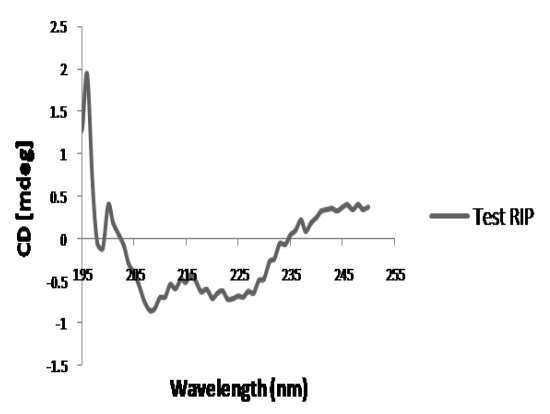

\section{Secondary structural analysis}

CD analyses for the test sample showed a protein profile with predominance of alphahelical elements two negative bands at 222 and $208 \mathrm{~nm}$ and a positive peak at $195 \mathrm{~nm}$. Since the test sample was not sequenced so for calculating Mean residue ellipticity (MRE), 260 which is the average residue number of some RIPs of around $32 \mathrm{KDa}$ size, was taken [Figure 3]. Further an online software BestSel was used to analyze data and assess the percentage of secondary structure present [Table 3]. The protein also showed homology with proteins such as Glycoside hydrolase, hence the mode of action of this protein might involve $\mathrm{N}$-glycosidic bond hydrolysis of ribosome sub unit.
B.

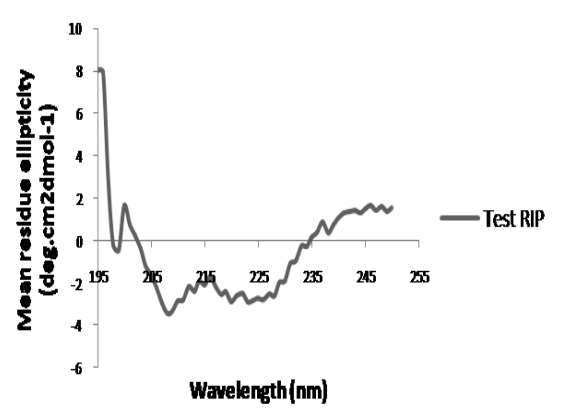

Ribosome Inactivating Proteins derived from natural sources can be used for the treatment of many diseases for which medication is still not available or only synthetic drugs are present. RIPs can also be used for other purposes such as anti-microbial, anti-viral etc. Hence, the present research in which a new RIP that showed anticancer properties could be useful for these studies in the future. It had been reported that numerous plant species belonging to different families, such as Cucurbitaceae, Poaceae etc., possess Ribosome-Inactivating Proteins (RIPs), although many plant species are still to be explored and some do not possess RIPs, including plant type model Arabidopsis thaliana (Arabidopsis Genome, I. 2000). Cucurbitaceae species used for the present study i.e. Trichosanthes dioica, has not been 
well studied earlier, except for the one study published, i.e. a $55 \mathrm{KDa}$ lectin TDSL (Ali. et al., 2004). Our results indicate a protein of around $32 \mathrm{KDa}$ from Trichosanthes dioica seeds having ribosome inactivating property. The size i.e. $32 \mathrm{KDa}$ and the test proving RIP activity using a rabbit reticulocyte kit suggest that the RIP thus isolated could be a Type I RIP but more testing and sequencing is required to verify this. In this study, the overall shift in protein concentration and the MTT assay both demonstrated that the isolated protein significantly affects cancerous cell lines and can therefore be used as an anticancer agent. In addition, unlike most previous research, a known RIP from Momordica charantia was used in this analysis as a positive control, which helped to explain or compare the efficacy of the test protein on different parameters with that of a known RIP. The test protein displayed less toxicity to normal PBLs than the known positive control that further confirmed that the test protein is a strong candidate as an anticancer agent. The results of the MTT assay were found to be compatible with the findings of the aforementioned protein concentration assay. Until now, while many researchers have addressed several questions about RIPs, several of the areas are still unclear and confusing. One of these areas of discussion is how RIPs act, that is the mode of action. When studied with the help of an online tool- BestSel the protein was found to share homology with proteins like glycoside hydrolase. Therefore, the mechanism of action of the isolated RIP may require hydrolysis of $\mathrm{N}$-glycosidic bonds in the ribosomal subunit to inactivate ribosomes. Secondary analysis of the structure (CD analysis) for the test sample showed a protein profile with predominance of alpha-helical elements (Table 4).

To summerise the findings it can be concluded that the isolated ribosome inactivating protein has anticancer properties. Thus, these protein properties can be further investigated for other applications such as anti-microbial, anti-viral, etc. This RIP as immune-toxin may also be a possibility if studied further and appropriate modifications are made in its structure, properties, etc. Upon studying the secondary structure, the protein showed homology with glycoside hydrolase enzyme, this proves that $\mathrm{N}$-glycosidase activity plays a key role in inactivating ribosome for this protein which might be true for many such proteins. However, many new RIPs are being investigated from other plant families, such as a recently isolated type-I RIP from Gypsophila elegans an ornamental plant (Kokorina et al., 2019), there are several species that have not yet been investigated for RIPs. These results pave the way for further analyses of the protein thus isolated. Also, various other Cucurbitaceae plant species can be investigated for such new RIPs and thus seek cheaper and better treatment options for diseases for which cure already exists, as well as for diseases for which there is still no efficient and precise treatment, such as cancer.

\section{Conflict of interest}

The authors declare no financial or commercial conflict of interest.

Abbreviations: [Use the following text style: RIP, Ribosome inactivating proteins; MTT, 3(4, 5-dimethylthiazol-2-yl)-2, 5-diphenyltetrazolium bromide, HL 60, Human promyelocytic leukemia cells, PBLs, Peripheral Blood Lymphocytes]

\section{References}

Ajji, P K., Walder, K., Puri, M. 2016. Functional Analysis of a Type-I Ribosome Inactivating Protein Balsamin from Momordica balsamina 
with Anti-Microbial and DNase Activity. Plant Foods Hum Nutr. 71, 265-271.

Arabidopsis Genome, I. 2000. Analysis of the genome sequence of the flowering plant Arabidopsis thaliana. Nature. 408, 796-815

Asano, K., Svensson, B., Poulsen, F.M. 1984. Isolation and characterization of inhibitors of animal cell-free protein synthesis from barley seeds. Carlsberg Research Communications.

49, 619-26.

Barbieri, L., Battelli, M.G., Stirpe F. 1993. Ribosome-inactivating proteins from plants. Biochimica et Biophysica Acta. 1154, 237-82.

Bass, H.W., Webster C., OBrian G.R., Roberts, J.K.M and Boston A. 1992. Maize ribosome-inactivating protein is controlled by the transcriptional activator Opaque- 2. Plant Cell. 4, 225-34.

Chaudhry, B., Mueller, U.F., Cameron Mills, V., Gough, S., Simpson, D. et al. 1994. The barley $60 \mathrm{kDa}$ jasmonateinduced protein (JIP60) is a novel ribosome-inactivating protein. The Plant Journal. 6, 815-24.

Freshney, R.I. 2010. (6th)., Culture of animal cells. a manual of basic technique and specialized applications, Wiley, New Jersey, pp. 373.

Gordon, M.C., David, J. 2005. Plants as a source of anti-cancer agents. Journal of Ethnopharmacology. 100, 72-79.

Griffiths, G.D., Leek, M.D., Gee, D.J. 1987. The toxic plant proteins ricin and abrin induce apoptotic changes in mammalian lymphoid tissues and intestine. The Journal of Pathology. $151,221-22$.

Hartley, M.R and Lord, J.M. 1993. Structure, function and applications of ricin and related cytotoxic proteins. In
Biosynthesis and Manipulation of Plant Products, ed. D Griesson. New York, Chapman \& H., pp. 210-39.

Hey, T.D., Hartley, M., and Walsh, T.A. 1995. Maize ribosome-inactivating protein (b- 32). Homologs in related species, effects on maize ribosomes and modulation of activity by propeptide deletions. Plant Physiology. 107, 1323-32.

Husain, J., Tickle, I.J., and Wood, S.P. 1994. Crystal structure of momordin., a type I ribosome inactivating protein from the seeds of Momordica charantia. FEBS Letters. 342,154-58.

Irvin, J.D. 1975. Purification and partial characterization of the antiviral protein from Phytolacca americana which inhibits eukaryotic protein synthesis. Archives of Biochemistry and Biophysics. 169, 522-28.

Kokorina, A., Weiseb, C., Samaa, S., and Weng, A. 2019. A new type 1 ribosome-inactivating protein from the seeds of Gypsophila elegans. M.Bieb. Photochemistry. 157,121-127.

Li, X.D., Chen, W.F., Liu, W.Y., and Wang, G.H. 1997. Large-scale preparation of two new ribosome-inactivating proteins - Cinnamomin and camphorin from the seeds of Cinnamomum camphora. Protein Expression and Purification. 10, 27-31.

Micsonai, A., Wien, F., Kernya, L., Lee, YH., Goto, Y., Refregiers, M., and Kardos, J. 2015. Accurate secondary structure prediction and fold recognition for circular dichroism spectroscopy. PNAS. $112(24)$, E3095-E3103.

Micsonai, A., Wien, F., Bulyaki, E., Judit, K., Moussong, E., Lee, Y-H., Goto, Y., Refregiers, M and Kardos, J. 2018. BeStSel, a web server for accurate protein secondary structure prediction and fold recognition from the circular 
dichroism spectra. Nucleic Acids Research .46, W315-W322.

Mlsna, D., Monzingo ,A.F., Katzin B.J., Ernst, S., and Robertus, J.D. 1993. Structure of recombinant ricin A chain at 2.3 A. Protein Science. 2, 429-35.

Monzingo, A.F., and Robertus, J.D. 1992. Xray analysis of substrate analogs in the ricin A-chain active site. Journal of Molecular Biology. 227, 1136-45.

Mundy, J., Leah, R., Boston, R., Endo, Y and Stirpe, F. 1994. Genes encoding ribosome-inactivating proteins. Plant Molecular Biology Reporter. 12, 6062.

Nielsen, K., and Boston, R.S. 2001. Ribosome-inactivating proteins, A plant perspective. Plant Molecular Biology. 52,785-86.

Olsnes, S., and Pihl, A. 1973. Isolation and properties of abrin, a toxic protein inhibiting protein synthesis. Evidence for different biological functions of its two constituent-peptide chains. European Journal of Biochemistry. 35, 179-85.

Olsnes, S., and Pihl, A. 1982. Chimeric toxins. Pharmacology \& Therapeutics. $15,355-81$.

Reinbothe, S., Reinbothe, C., Lehmann, J., Becker W., Apel, K., and Parthier, B. 1994. JIP60., a methyl jasmonateinduced ribosome-inactivating protein involved in plant stress reactions. Proceedings of the National Academy of Sciences of the United States of America. 91, 7012-16.

Seetharaman, K., Waniska, R.D., and Rooney,
L.W. 1996. Physiological changes in sorghum antifungal proteins. Journal of Agricultural and Food Chemistry. 44, 2435-41.

Singh, R.C., Alam, A., and Singh, V. 2003. Purification characterization and chemical modification studies on translation inhibitor protein from Luffa Cylindrica. Indian Journal of Biochemistry \& Biophysics. 40, 3139.

Smith P K., Krohn R I., Hermanson G T., Mallia A K., Gartner F H. et al. 1985. Measurement of protein using bicinchoninic acid. Analytical Biochemistry 150, 76-85.

Stirpe, F., Gasperi-Campani, A., Barbieri, L., Lorenzoni, E., Montanaro, L. et al. 1978. Inhibition of protein synthesis by modeccin., the toxin of Modecca digitata. FEBS Letters. 85, 65-67.

Sultan, N.A.M., Kenoth, R., and Swamy, M.J. 2004. Purification., physicochemical characterization., saccharide specificity., and chemical modification of a $\mathrm{Gal} / \mathrm{GalNAc}$ specific lectin from the seeds of Trichosanthes dioica. Archives of Biochemistry and Biophysics. 432, 212-221.

Walsh, T.A., Morgan, A.E., and Hey, T.D. 1991. Characterization and molecular cloning of a proenzyme form of a ribosome inactivating protein from maize, novel mechanism of proenzyme activation by proteolytic removal of a 2.8-kilodalton internal peptide segment. The Journal of Biological Chemistry. 266, 23422-27.

\section{How to cite this article:}

Tapu Ghosh, Laishram Indira Singha and Keshab Barman. 2020. Isolation and Characterization of a Novel RIP from Trichosanthes dioica having Anticancer Activity. Int.J.Curr.Microbiol.App.Sci. 9(09): 232-242. doi: https://doi.org/10.20546/ijcmas.2020.909.029 